\title{
FGF9, activin and TGF $\beta$ promote testicular characteristics in an XX gonad organ culture model
}

\author{
Sonja E Gustin ${ }^{1}$, Jessica M Stringer ${ }^{1}$, Kirsten Hogg ${ }^{1}$, Andrew H Sinclair ${ }^{2, *}$ and \\ Patrick S Western ${ }^{1, *}$ \\ ${ }^{1}$ Centre for Genetic Diseases, Hudson Institute of Medical Research and Department of Molecular and Translational \\ Science, Monash University, Clayton, Victoria, Australia and ${ }^{2}$ Murdoch Children's Research Institute and \\ Department of Paediatrics, University of Melbourne, Royal Children's Hospital, Parkville, Victoria, Australia \\ Correspondence should be addressed to P S Western; Email: patrick.western@hudson.org.au
}

*(A H Sinclair and P S Western contributed equally to this work)

\begin{abstract}
Testis development is dependent on the key sex-determining factors SRY and SOX9, which activate the essential ligand FGF9. Although FGF9 plays a central role in testis development, it is unable to induce testis formation on its own. However, other growth factors, including activins and TGFßs, also present testis during testis formation. In this study, we investigated the potential of FGF9 combined with activin and TGF $\beta$ to induce testis development in cultured XX gonads. Our data demonstrated differing individual and combined abilities of FGF9, activin and TGF $\beta$ to promote supporting cell proliferation, Sertoli cell development and male germ line differentiation in cultured XX gonads. FGF9 promoted proliferation of supporting cells in XX foetal gonads at rates similar to those observed in vivo during testis cord formation in XY gonads but was insufficient to initiate testis development. However, when FGF9, activin and TGF $\beta$ were combined, aspects of testicular development were induced, including the expression of Sox 9 , morphological reorganisation of the gonad and deposition of laminin around germ cells. Enhancing $\beta$-catenin activity diminished the testis-promoting activities of the combined growth factors. The male promoting activity of FGF9 and the combined growth factors directly or indirectly extended to the germ line, in which a mixed phenotype was observed. FGF9 and the combined growth factors promoted male germ line development, including mitotic arrest, but expression of pluripotency genes was maintained, rather than being repressed. Together, our data provide evidence that combined signalling by FGF9, activin and TGF $\beta$ can induce testicular characteristics in XX gonads.

Reproduction (2016) 152 529-543
\end{abstract}

\section{Introduction}

Male or female development is initiated in the developing foetus when the bipotential gonadal primordium is committed to form a testis or an ovary. In mice, testis development is initiated by expression of the Y-chromosome-linked testis-determining gene Sry (sex-determining region of chromosome Y). SRY promotes pre-Sertoli cell proliferation and expression of the dominant male sex-determining transcription factor Sox9 (Sry-box containing gene 9), leading to commitment of bipotential pre-supporting cells to Sertoli cell development and testis differentiation (Lin \& Capel 2015). As Sertoli cells proliferate, they organise into laminin-delineated testis cords that surround germ cells, thereby defining the interstitial space where steroidogenic Leydig cells differentiate (Lin \& Capel 2015).

SOX9 directly or indirectly promotes the expression of a number of downstream genes, including Fgf9 (fibroblast growth factor 9), AMH (anti-Müllerian hormone) and CYP26B1 (cytochrome P450, family 26 , subfamily $B$, polypeptide 1 ), which are involved in Müllerian duct regression and germ cell differentiation respectively (Behringer et al. 1994, Colvin et al. 2001, Bowles et al. 2006). FGF9 promotes the maintenance of Sox9 expression and the proliferation and differentiation of Sertoli cells, but FGF9 is insufficient to initiate testis development (Colvin et al. 2001, Schmahl et al. 2004, Kim et al. 2006).

In addition to Fgf9, Inhba, Inhbb and Tgfb1-3 are expressed in $\mathrm{XY}$ foetal gonads as testis cords form (Mendis et al. 2011, Miles et al. 2013). These genes encode activin $\mathrm{A}$ and $\mathrm{B}$ and transforming growth factor beta 1-3. Blocking activin/TGF $\beta$ signalling at E11.5 or E12.5 significantly reduces Sertoli cell proliferation and disrupts testis cord formation (Miles et al. 2013), indicating that activin-TGF $\beta$ signalling promotes testis formation in the critical sex-determining window at 
E11.5. However, testes develop in mice that lack Inhba, Inhbb or individual Tgf $\beta$ genes, demonstrating that they are individually dispensable for male sex determination (Shull et al. 1992, Memon et al. 2008, Archambeault \& Yao 2010, Moreno et al. 2010, Mendis et al. 2011), although the possibility that these factors compensate for one another's function in testis development has not been addressed.

Ovarian development is promoted by complementation of the transcription factor FOXL2 (forkhead box L2) and RSPO1 (R-spondin homolog 1)/WNT4 (winglessrelated MMTV integration site 4$) / \beta$-catenin signalling in GATA4-expressing supporting cells (Chassot et al. 2014, Tevosian 2014). During early ovarian development, proliferative GATA4-expressing cells activate expression of the cell cycle inhibitor p27KIP1 (p27) and FOXL2 as they form non-proliferative granulosa cells (Mork et al. 2012, Rastetter et al. 2014, Gustin et al. 2016). Although loss of FOXL2 function does not result in female-tomale sex reversal in humans, individuals carrying FOXL2 mutations are susceptible to primary ovarian insufficiency (Crisponi et al. 2001). Consistent with this, morphologically normal foetal ovaries form in mice that lack Fox/2, but ovarian gene expression programmes are disrupted and follicles fail to properly activate at postnatal stages (Schmidt et al. 2004, Uda et al. 2004, Garcia-Ortiz et al. 2009).

WNT4 and RSPO1 signal through $\beta$-catenin, which plays a key role in repressing male developmental pathways in the XX foetal gonad (Chassot et al. 2014). $W N T / \beta$-catenin signalling is regulated through glycogen synthase kinase (GSK), which phosphorylates $\beta$-catenin, targeting it for proteasomal degradation (Bennett et al. 2002). Conversely, inhibition of GSK stabilises $\beta$-catenin, promoting ovarian development (Bernard et al. 2012). Excess $\beta$-catenin function antagonises Sox9 expression and results in partial male-to-female sex reversal, while loss of RSPO1 or $\beta$-catenin function results in partial female-to-male sex reversal (Chassot et al. 2008, Maatouk et al. 2008, Tomizuka et al. 2008). Loss of WNT4 function does not result in sex reversal, but permits development of the testis-specific coelomic vessel in XX individuals, expression of male steroidogenic enzymes and disruption of germ cell development (Vainio et al. 1999, Chassot et al. 2008, Tomizuka et al. 2008). Although ovaries form in XX foetuses that lack WNT4 signalling, structures similar to testis cords arise in late-stage XX gonads. Taken together, these findings demonstrate that activity of WNT4 and RSPO1 promotes sufficient $\beta$-catenin activity to promote ovary development (Chassot et al. 2014).

Somatic cells in the testis and ovary also produce signals that commit primordial germ cells to the spermatogenic or oogenic pathways respectively (Kocer et al. 2009). In mice, XY germ cells commit to the spermatogenic pathway at embryonic day (E)12.5 and enter mitotic arrest between E12.5 and E14.5, which involves regulation of the $\mathrm{G}_{1}$-S phase checkpoint (Adams \& McLaren 2002, Western et al. 2008, 2011, Spiller et al. 2010). Male germ line development is characterised by upregulation of Nanos2, Piwil2 and Dnmt3/; strong nuclear localisation of DPPA4 protein (developmental pluripotency associated 4); and repression of pluripotency factors NANOG, SOX2 and OCT4 (Suzuki \& Saga 2008, Barrios et al. 2010, Bowles et al. 2010, Western et al. 2010, 2011). In the developing ovary, germ cells express Stra8 (stimulated by retinoic acid gene 8 ) and enter meiosis between E13.5 and E15.5, which is marked by distinctive nuclear localisation of phosphorylated $\mathrm{H} 2 \mathrm{AX}(\gamma \mathrm{H} 2 \mathrm{AX})$ (Baltus et al. 2006, Bowles et al. 2006, Koubova et al. 2006, Miles et al. 2010). Cyp26b1 is expressed by somatic cells of the developing testis and is considered essential for metabolising retinoic acid (RA), thereby preventing Stra8 expression and entry of germ cells into meiosis (Bowles et al. 2006, Koubova et al. 2006). In addition, FGF9 represses Stra8 and germ cell entry into meiosis, while promoting male germ line development (Suzuki \& Saga 2008, Barrios et al. 2010, Bowles et al. 2010). Although Nanog and Sox2 are transcriptionally repressed in both $X X$ and $X Y$ germ cells, NODAL is thought to maintain pluripotency slightly longer in $X Y$ germ cells (Spiller et al. 2012, Miles et al. 2013).

FGF9 is indispensable for testis development, but is not sufficient to initiate it. In addition to Fgf9, Inhba, Inhbb and Tgf $\beta 1-3$ are all expressed in the developing testis and blocking activin-TGF $\beta$ signalling in E11.5 and E12.5 developing testes disrupts Sertoli cell proliferation and testis cord formation. Based on these observations, we proposed that the combined actions of FGF9, activin and TGF $\beta$ signalling might promote testis development in XX gonads. As expected, FGF9 promoted supporting cell proliferation but was insufficient to induce testis development in XX gonads. However, FGF9 combined with activin and TGF $\beta$ induced testicular characteristics in cultured XX gonads. This activity directly or indirectly extended to the germ line, in which characteristic male developmental processes were induced, although pluripotency was maintained. Moreover, the testispromoting activity of these ligands was inhibited by facilitating $\beta$-catenin signalling. Combined, these data indicate that FGF9, activin and TGF $\beta$ cooperatively promote testis development in the critical sexdetermining window in mice.

\section{Materials and methods}

\section{Animals}

Mice used in all experiments were derived from pure 129T2SvJ OG2 (Szabo et al. 2002) (Oct4-GFP; octamer-binding transcription factor 4, also known as Pou5f1) transgenic male mice $x$ Swiss female matings. The presence of a vaginal plug in the morning was used to indicate mating and was recorded 
as E0.5. All animal procedures were carried out under Monash University Animal Ethics Committee and Murdoch Childrens Research Institute Animal Ethics Committee approvals.

\section{Organ culture}

E11.5 gonad/mesonephros and E12.5 gonad/mesonephros samples were collected from Oct4-GFP transgenic embryos and sexed using PCR as described previously (McFarlane et al. 2013, Miles et al. 2013). XX or XY gonad/mesonephros tissues were placed onto $25 \mathrm{~mm}$ Millicell Biopore $0.4 \mu \mathrm{m}$ membranes (Millipore) in six-well plates containing $1200 \mu \mathrm{L}$ organ culture media $(15 \mathrm{mM}$ Hepes, $1 \mathrm{X}$ non-essential amino acids, $1 \mathrm{mg} / \mathrm{mL}$ $N$-acetylcysteine, $55 \mu \mathrm{M} \beta$-mercaptoethanol, 1X penicillin/ streptomycin and 10\% FCS in DMEM/F12 with Glutamax). Phosphate-buffered saline (PBS) was included between wells and in empty wells to maintain a humid environment. FGF9 $(50 \mathrm{ng} / \mathrm{mL})$, TGF $\beta 1(25 \mathrm{ng} / \mathrm{mL})$, activin A/activin B $(25 \mathrm{ng} / \mathrm{mL}$ of each) (R\&D Systems) or Chir99021 (GSKi, $3 \mu \mathrm{M}$; Cayman Chemicals, Ann Arbor, MI, USA) (Bennett et al. 2002, Ying et al. 2008) were added to the culture medium at the outset of the experiment. These concentrations of growth factors are similar to those used in a range of studies of gonad, germ cell and pluripotent cell development (DiNapoli et al. 2006, Rosairo et al. 2008, Vallier et al. 2009, Bowles et al. 2010, Kjartansdottir et al. 2015, Tepekoy \& Akkoyunlu 2016), whereas Chir99021 robustly induces $\beta$-catenin signalling (Naujok et al. 2014). Tissues were cultured for $24,72,96$ or $120 \mathrm{~h}$ in $5.0 \% \mathrm{CO}_{2}$ at $37^{\circ} \mathrm{C}$ with organ culture media changed daily. All organ cultures were replicated at least two times using two to four individual gonads per treatment. Gonads were photographed under bright field and fluorescence optics and were carefully removed from culture membranes. Gonads were dissociated into single cells using trypsin and fixed for flow cytometric analysis (Wakeling et al. 2013), or fixed whole for immunofluorescence (IF) in 4\% paraformaldehyde (PFA) or snap frozen for RNA preparation.

\section{$R N A$ isolation, reverse transcription and quantitative $P C R$}

For qRT-PCR experiments, RNA was extracted from three to four cultured gonads pooled together per sample using Qiagen micro-RNeasy columns, DNase treated and integrity confirmed using a Bioanalyzer 2100 (Agilent), and quantified using the Qubit RNA assay (Life Technologies). RNA samples used had RIN values between 7.0 and 10.0. Reverse transcription was performed using Superscript III First-Strand cDNA synthesis kit (Life Technologies) according to the manufacturer's instructions. qRT-PCR was performed as described previously (Western et al. 2008, 2010, van den Bergen et al. 2009) using SYBR green chemistry and validated primers (Supplementary Table 1, see section on supplementary data given at the end of this article) and an ABI7900 (Life Technologies) instrument. qRT-PCR results were analysed using manufacturer's software. Relative expression levels were determined by normalisation against verified reference genes Mapk1, Sdha and Canx (van den Bergen et al. 2009) or against $D d x 4$ to correct for germ cell number. Data represent one to three experiments each performed on biological triplicate samples, with PCRs performed in technical triplicate. Relative gene expression was calculated using the $2^{-\Delta \Delta C T}$ method (Livak \& Schmittgen 2001). Fold change was calculated based on the highest expression value and expression was normalised relative to the XX control sample set at 1.0. Data were analysed using ANOVA with Tukey's post hoc $t$-tests and with Bartlett's test to compare variances. When variances were unequal, Kruskal-Wallis ANOVA (nonparametric) test with Dunn's multiple comparisons test was used. All statistical analyses/calculations were performed in Prism 6 (version 6.0e; GraphPad Software). A $P$-value less than 0.05 was considered significant.

\section{Flow cytometry}

For in vivo analysis of gonadal cell proliferation, pregnant mothers were injected intraperitoneally (i.p.) with $20 \mathrm{mg} / \mathrm{kg}$ EdU (5-ethynyl-2-deoxyuridine). After $2 \mathrm{~h}$ of the i.p. injection, the mothers were killed, foetuses removed, gonads dissected, dissociated and the cells fixed for $15 \mathrm{~min}$ at RT in Click-iT Fixative (Life Technologies) for flow cytometry. For analyses of cell proliferation in cultured gonads, EdU was added to the organ culture media at a final concentration of $20 \mu \mathrm{M}$ for the final $2 \mathrm{~h}$ of culture, after which gonads were collected, dissociated into single cells and fixed with $4 \%$ PFA in PBS. Flow cytometry was carried out essentially as described (Wakeling et al. 2013, Gustin et al. 2016) using cells from 0.5 to 2 gonads/sample, depending on age. For example, in vivo analysis of Sertoli cell proliferation (Fig. 1A) was performed using the following approach: fixed cells were co-stained using a rabbit-raised SOX9 antibody to identify Sertoli cells and goatraised $\mathrm{MVH}$ antibody to identify germ cells as the EdU staining buffers destroy eGFP fluorescence. The SOX9 and MVH antibodies were detected using anti-rabbit-Biotin-Pacific Blue Streptavidin and anti-goat-Alexa-488 secondary antibodies respectively. DNA synthesis was measured via incorporation of EdU and detection with click-iT 647 azide. After staining, the cells were resuspended in $300 \mu \mathrm{L}$ PBS containing $20 \mu \mathrm{g} / \mathrm{mL}$ propidium iodide to stain DNA, allowing individual cell DNA content to be determined. Cells were analysed on a BD FACS Canto flow cytometry instrument. The outputs represent the relative proliferation (EdU incorporation) of FOXL2+ cells in XX gonads at E12.5 or SOX9+ in XY gonads at E11.5, E12.5, E13.5 and E14.5 days of development.

Staining protocols for other flow cytometry experiments were similar with the exception that antibodies specific for GATA4, SOX9, p27, STRA8, DPPA4 or $\gamma \mathrm{H} 2 \mathrm{AX}$ were used in conjunction with germ cell markers Oct4-GFP or goat- or rabbit-raised anti$\mathrm{MVH}$ (antibodies are listed in the Supplementary Information). Average individual cell staining intensities were collected for p27, STRA8, DPPA4 and $\gamma \mathrm{H} 2 \mathrm{AX}$, allowing quantification of the relative levels of these proteins in somatic and germ cells. Where data were combined from independent flow cytometry experiments, the control-treated samples were used to normalise staining intensity between runs, with all experimental samples then compared with control. Primary antibodies used are listed in Supplementary Table 2. Secondary antibodies used were 1/300 donkey anti-goat or rabbit Alexa-647, 1/300 donkey anti-goat or rabbit biotin $1 / 500$, followed by $1 / 500$ 
A

Supporting cells XX FOXL2+ ; XY SOX9+

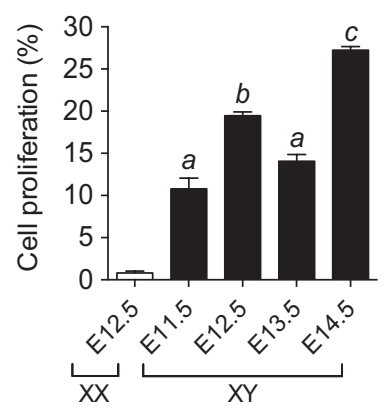

B

i.

i. GATA4+ cells

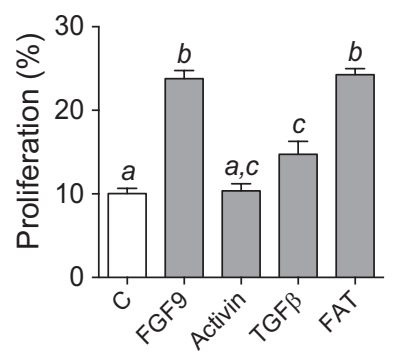

E12.5 XX gonad + $24 \mathrm{~h}$ culture

ii.

GATA4+ cells

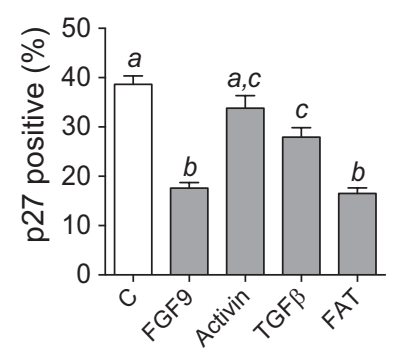

iii.

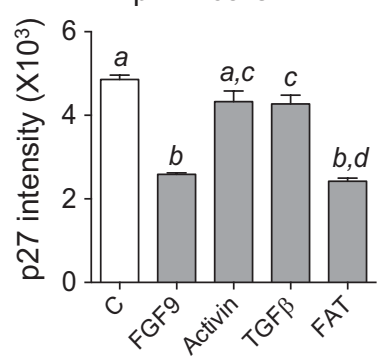

Figure 1 FGF9 and TGF $\beta 1$ acted as mitogens in cultured foetal gonads. (A) In vivo proliferation rates of SOX9 expressing cells in XY gonads at E11.5, E12.5, E13.5 and E14.5 compared with FOXL2 expressing cells at E12.5 in XX gonads assessed using flow cytometry. $a, b$ and $c$ are significantly different. (ANOVA with Tukey's multiple comparison test; $P<0.05$. Values are expressed as mean \pm S.E.M.; $n \geq 3$.) (B) Flow analysis in E12.5 XX gonads cultured for $24 \mathrm{~h}$ with control (C), FGF9, activin, TGF $\beta$ or combined (FAT) (i) Proliferation in GATA4+ cells; (ii) Percentage of p27+ cells in the GATA4+ population; (iii) p27 staining intensity in the p27+ population. $a, b, c$ and $d$ are statistically different from each other. (ANOVA with Tukey's multiple comparison test.) Values are expressed as mean \pm S.E.M.; $n \geq 3$.

Streptavidin-Pacific Blue $(405 \mathrm{~nm})$ and 1/300 donkey anti-goat or rabbit Alexa-488 (Life Technologies). Gating for each primary antibody (Supplementary Fig. 1) was performed against negative control tissues that did not express that protein or was not treated with EdU: mesonephros or tail (p27 (CDKN1B), STRA8, DPPA4, $\gamma \mathrm{H} 2 \mathrm{AX}$, GATA4 and EdU) or gonad of the opposite sex (SOX9, AMH and FOXL2), depending on the antibody used. Cell cycle analysis was performed using propidium iodide to determine DNA content and EdU incorporation during S-phase to determine proliferation (Wakeling et al. 2013, Gustin et al. 2016). Mean individual germ cell staining intensities were acquired using area under the curve in either Pacific Blue 405 nm (405-A) or Alexa-fluor 647 nm (647-A) (Life Technologies) channels for the whole germ cell population isolated using Oct4-GFP fluorescence or MVH staining in the $488 \mathrm{~nm}$ channel. All flow cytometry data was analysed using Flowjo v.X.0.7. software. Data represent three to eight biologically distinct samples and statistical significance was determined using ANOVA with Tukey's multiple comparison test for experimental groups $>3$, or unpaired $t$-test, with $F$-test to compare variances for groups of two. Where variances were unequal, a non-parametric test was used (Mann-Whitney). A $P$-value less than 0.05 was considered significant.

\section{Tissue fixation and IF}

Cultured gonads were fixed in PBS containing 4\% PFA for 20-45 min (depending on age) at RT and mounted in optimal cutting temperature. Cryosections were cut at $10 \mu \mathrm{m}$ and IF was performed as described previously (Western et al. 2008, 2011, Miles et al. 2010). Details of primary antibodies are provided in Supplementary Table 2. Secondary antibodies were used at 1/300 dilution and included: Donkey anti-goat or rabbit Alexa-647 and donkey anti-goat or rabbit Alexa-594 (Life Technologies), whereas eGFP fluorescence was detected directly in the $488 \mathrm{~nm}$ channel. Where the 647 and 594 red channels were used together, one colour is shown in pseudocoloured cyan. All IF experiments were replicated at least two times using two to four individual gonads per replicate.

\section{Results}

\section{Testis formation is characterised by two phases of high in vivo Sertoli cell proliferation}

A key characteristic of male sex determination includes high supporting cell proliferation, but the relative proliferation of Sertoli cells during sex determination and early testis development has not been quantitatively documented. To determine relative rates of in vivo Sertoli cell proliferation in developing testes, we exposed mice to EdU for $2 \mathrm{~h}$ at E11.5, E12.5, E13.5 and E14.5 of pregnancy. Foetal gonads were collected $2 \mathrm{~h}$ after EdU injection and Sertoli cell proliferation quantified relative to $X X$ granulosa cell proliferation using SOX9 (XY) or FOX2 (XX, E12.5 only) antibody staining, EdU labelling and flow cytometry. At E12.5, FOXL2-positive cells in XX gonads were not proliferative as less than $1 \%$ progressed through S-phase in the $2 \mathrm{~h}$ EdU labelling period. Sertoli cell proliferation was relatively low at E11.5 XY gonads despite high levels of SOX9 expression in these cells (Fig. 1A). However, Sertoli cell proliferation rose between E11.5 and E12.5 coincident with testis cord formation and declined again at E13.5 (Fig. 1A). Sertoli cell proliferation then increased at E14.5 in a second wave of high proliferation coincident with testis cord expansion (Fig. 1A).

\section{FGF9 and TGF $\beta$ acted as mitogens for pre-supporting cells in ex vivo gonad cultures}

Sertoli cells and granulosa cells are derived from common GATA4-expressing bivalent supporting cells in $X Y$ and $X X$ E11.5 gonads. These supporting cell precursors are presumably responsive to growth factors present in the developing testis, which include FGF9, activin and TGF $\beta$. To determine the relative abilities of FGF9, TGF $\beta$ and activin to drive proliferation of pre-supporting cells, we collected E12.5 XX gonads 
and cultured them with combinations of FGF9 $(50 \mathrm{ng} / \mathrm{mL}$ ), activin (activin A and activin B each at $25 \mathrm{ng} / \mathrm{mL})$ and TGF $\beta(25 \mathrm{ng} / \mathrm{mL})$ for $24 \mathrm{~h}$. As XX supporting cells do not express high levels of SOX9, we used flow cytometry to analyse proliferation in GATA4+ cells. Moreover, as previous studies have demonstrated high levels of the cell cycle inhibitor p2 $7^{\mathrm{KIP} 1}$ (p27) in non-proliferative XX supporting cells, we used flow cytometry to determine whether FGF9, activin or TGF $\beta$ reduced p27 levels in the XX supporting cells of XX gonads.

Treatment of E12.5 XX gonads with FGF9 for $24 \mathrm{~h}$ induced a similar rate of proliferation in GATA4+ cells as that observed in vivo for SOX9+ Sertoli cells in E12.5 XY gonads $(23.8 \pm 2.3 \%$ vs $19.5 \pm 10.2 \%$ EdU positive respectively; Fig. 1B i compared with $1 \mathrm{~A}$ ), demonstrating potent mitogenic activity for FGF9 in the foetal gonad. In addition, FGF9 significantly $(P<0.001)$ reduced the proportion of $\mathrm{p} 27+$ cells in the GATA4+ population and the average $\mathrm{p} 27$ fluorescence intensity in remaining p27+ cells (Fig. 1B ii, iii). TGF $\beta$ also promoted a significant $(P<0.05)$ increase in proliferation and decreased the proportion of p27+ cells in the GATA4+ population and decreased p27 levels in the p27+ population (Fig. 1B). However, activin did not alter these parameters. Consistent with these data, combined treatment of E12.5 XX gonads with FGF9 $(50 \mathrm{ng} / \mathrm{mL})$, activin $\mathrm{A} / \mathrm{B}(25 \mathrm{ng} / \mathrm{mL}$ each) and TGF $\beta$ $(25 \mathrm{ng} / \mathrm{mL})$ (FAT) did not further increase proliferation of XX GATA4+ cells or further decrease p27 levels in the p27+ population compared with FGF9 treatment alone (Fig. 1B ii, iii).
A
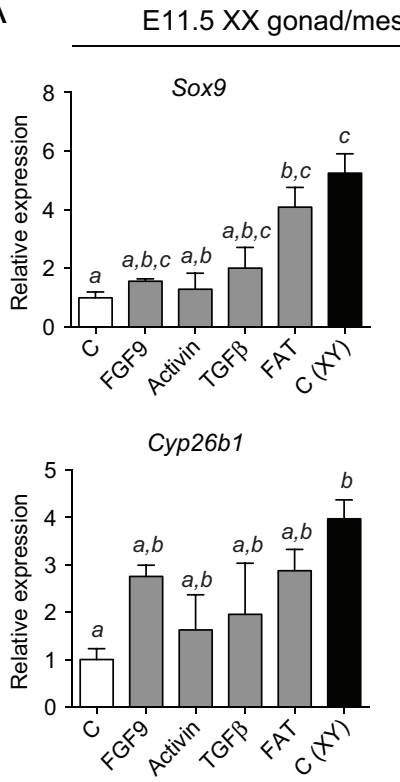

B

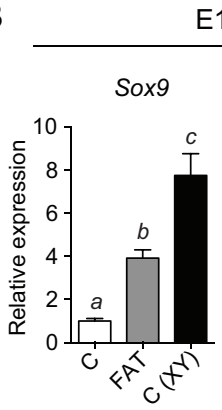

E11.5 XX gonad/mesopnephros $+24 \mathrm{~h}$

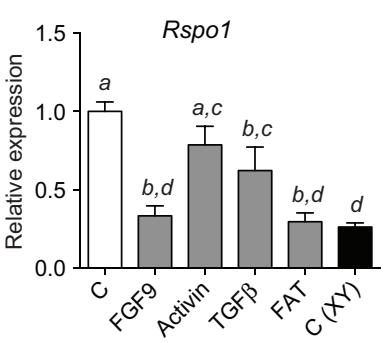

Fox12

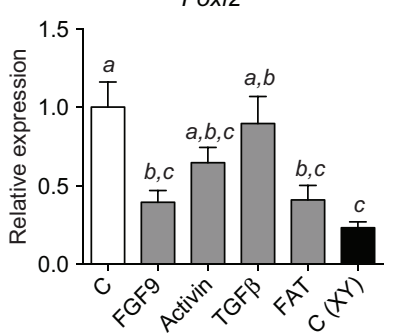

C
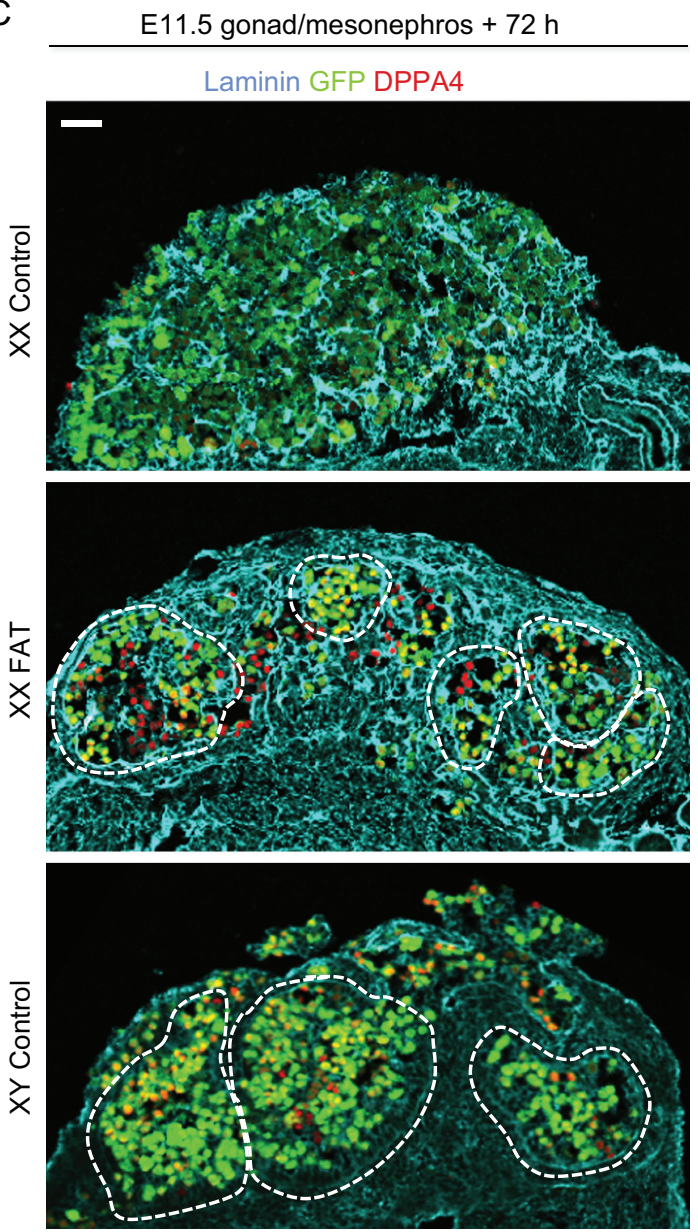

Figure 2 Combined, FGF9, activin and TGF $\beta$ repressed ovarian genes and promoted testicular characteristics in cultured E11.5 gonads. (A) qRT-PCR analysis of Sox9, Cyp26b1, Fox/2 and Rspo1 expression in E11.5 XX gonad/mesonephros tissues cultured for $72 \mathrm{~h}$ with control (C), FGF9, activin, TGF $\beta$ and FAT media and XY samples treated with control media (C (XY)). (B) qRT-PCR analysis of Sox9, Cyp26b1, Fox/2 and Rspo1 expression in E11.5 XX gonad/mesonephros tissues cultured for $24 \mathrm{~h}$ with control (C) or FAT media and XY samples treated with control media $(C(X Y))$. In (A and B), expression is relative to the XX control sample set at 1.0, normalised against Mapk1, Sdha and Canx. a, b, c and d are statistically different (ANOVA with multiple comparison test; $P<0.05)$. Values are expressed as average \pm S.E.M., $n=3-6$. (C). IF images of E11.5 XX (and XY control) gonad/mesonephros/whole gonad sections cultured for $72 \mathrm{~h}$ with control or FAT media and analysed with antibodies specific for laminin (cyan) and DPPA4 (red). Germ cells are marked by Oct4-GFP (green). Dashed white lines outline testis cord-like structures in XX gonads treated with FAT and testis cords in XY gonads. Scale bars: $50 \mu \mathrm{m}$. 


\section{Combined, FGF9, activin and TGFß induced testicular characteristics in $X X$ gonads}

Although FGF9 is required for testis development, it is alone insufficient to initiate testis formation. As activin/ TGF $\beta$ signalling is also required for testis cord formation, we next tested whether combinations of FGF9, activin and/or TGF $\beta$ could induce testis development in XX gonads. Constructing a multi-transgenic mouse model that overexpresses Fgf9, Inhba, Inhbb and Tgfb1-3 in a spatiotemporal pattern that recapitulates normal gonad development was not considered feasible. We therefore examined the combined ability of FGF9, activin and TGF $\beta$ to promote testis development in XX gonads using an established gonad organ culture system.

Gonad/mesonephros tissues were isolated from E11.5 foetuses and cultured with combinations of FGF9, activin and/or TGF $\beta 1$ or control medium for $72 \mathrm{~h}$. To determine whether FGF9, activin and/or TGF $\beta$ promoted expression of testis development genes, we performed qRT-PCR to measure the mRNA levels of Sox9 and Cyp26b1 and the ovarian genes Fox/2 and Rspo1 in XX gonads cultured for $72 \mathrm{~h}$. Treatment of E11.5 XX gonads with FAT for $72 \mathrm{~h}$ resulted in upregulation of Sox9 in XX gonads to levels comparable with those detected in $\mathrm{XY}$ gonads, but Sox9 expression was unaffected by treatment with FGF9, activin or TGF $\beta$ alone (Fig. 2A). Compared with XX controls, transcription of Cyp26b1 increased two- to three-fold in the presence of FGF9 or FAT (paired $t$-tests; $P<0.01$ and $P<0.05$ respectively), but not with activin or TGF $\beta$ alone (Fig. 2A). Transcription of Rspo 1 was significantly lower in XX gonads treated with FGF9, TGF $\beta$ or FAT (Fig. 2A) compared with controls, but Fox/2 levels were reduced only by FGF9 and FAT (Fig. 2A). Treatment of E11.5 XY gonads for $72 \mathrm{~h}$ with FGF9, activin, TGF $\beta$ or FAT did not affect transcription of Sox9, Cyp26b1 or Rspo1, but both FGF9 and FAT moderated levels of Fox/2 (Supplementary Fig. 2A).

The response of these genes to growth factor treatment occurred early as treatment of E11.5 XX gonad/mesonephros complexes for $24 \mathrm{~h}$ with FAT was sufficient to drive increased transcription of Sox9 and Cyp26b1 and decrease levels of Rspo 1 and Fox/2 (Fig. 2B). Despite FAT induction of Sox9, there was no effect on transcription of Amh or Dhh, which are also produced by Sertoli cells (Supplementary Fig. 2B), and involved in Müllerian duct regression and Leydig and peritubular myoid cell differentiation respectively. However, the foetal Leydig cell marker Inhba, which encodes activin A, was robustly induced by FAT after 24 or $72 \mathrm{~h}$ of culture, indicating that this gene may respond relatively directly to FAT (Supplementary Fig. 2C).

\section{FAT promoted formation of testis cord-like structures in cultured E11.5 XX gonads}

The induction of Sox9, Cyp26b1 and Inhba expression and the repression of Rspo 1 and Fox/2 (Fig. 2) indicated that FAT might induce testicular development in E11.5 gonad/mesonephros cultures. To determine whether testis cords were forming in FAT-treated gonads, we performed IF for laminin, which delineates the basement membrane of testis cords. In XX gonads cultured in control medium for $72 \mathrm{~h}$, laminin was distributed throughout the gonad in a discontinuous, unorganised pattern and did not enclose germ cells in cords (Fig. 2C, top panel). In contrast, groups of GFP-expressing germ cells were enclosed inside laminin-delineated spaces in E11.5 XX gonads treated for $72 \mathrm{~h}$ with FAT (Fig. 2C, middle panel), similar to germ cells within testis cords (Fig. 2C, bottom panel). Although these testis-like cords were not always distributed throughout the whole gonad, similar structures were not observed in controltreated XX gonads.

To determine whether key proteins involved in gonad development were altered by growth factor treatment, we cultured additional E11.5 XX gonads with or without FAT for $72 \mathrm{~h}$ and performed double IF using antibodies against laminin, SOX9, AMH, FOXL2 and the male germ line marker DPPA4. Consistent with our previous experiments, FAT induced laminin-defined cord-like structures containing germ cells that expressed relatively high levels of DPPA4 (Fig. 3A). Moreover, FAT-treated E11.5 gonads contained SOX9-expressing somatic cells that were associated with germ cells enclosed in cord-like structures (Fig. 3B), although substantially fewer SOX9+ cells were detected in FAT-treated XX gonads compared with control-treated $X Y$ gonads. By comparison, cells positive for SOX9 protein were very rarely detected in E11.5 XX gonads treated with FGF9 alone and were not detected in $\mathrm{XX}$ samples cultured in control medium (Fig. 3B; control sample shown). Although the number of FOXL2+ cells was reduced in FAT-treated gonads, some FOXL2+ cells remained and tended to group in cord-like structures associated with rare $\mathrm{AMH}+$ cells (Fig. $3 \mathrm{C}$ ).

\section{Facilitating $\beta$-catenin signalling inhibited the testis-promoting activity of FAT}

It is well established that $\beta$-catenin signalling promotes ovarian development and opposes testis development. As inhibition of GSK facilitates $\beta$-catenin signalling, we used a potent and highly specific GSK $\alpha / \beta$ inhibitor, Chir99021 (GSKi), to block GSK and test whether enhancing $\beta$-catenin signalling might reduce the ability of FAT to promote testicular features in $X X$ gonads. Indeed, gonads cultured with FAT+GSKi were similar to XX control gonads with no laminin-defined cords apparent, low DPPA4 expression in germ cells, no detectable SOX9 or AMH-positive cells and numerous, scattered FOXL2-positive cells (Fig. 3A-C). Consistent with this, GSKi prevented FAT induction of Sox 9 and Cyp26b 1 transcription and led to a moderate recovery in Fox/2 transcription to levels intermediate 


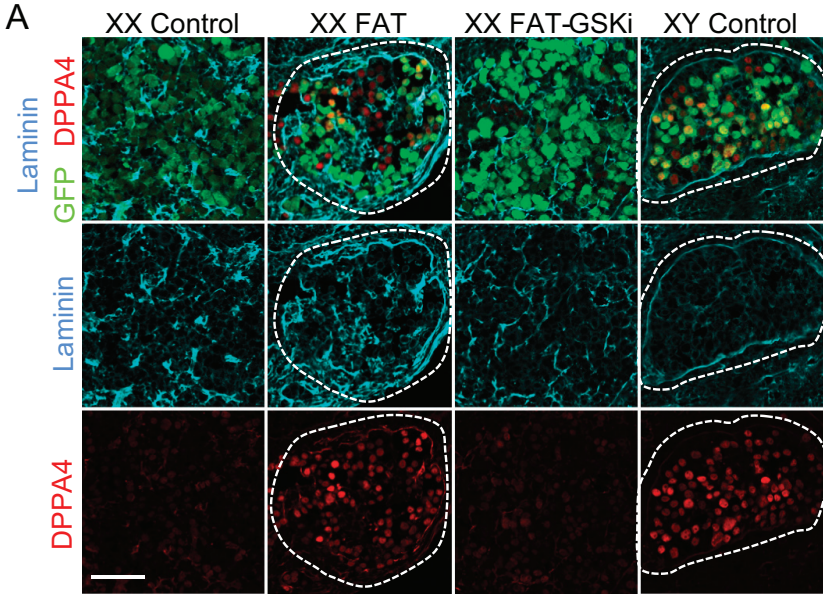

E11.5 gonad/mesonephros $+72 \mathrm{~h}$

B

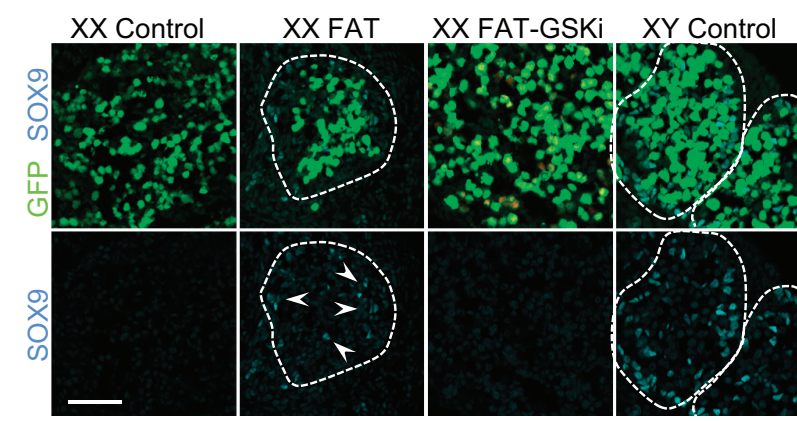

E11.5 gonad/mesonephros $+72 \mathrm{~h}$
C

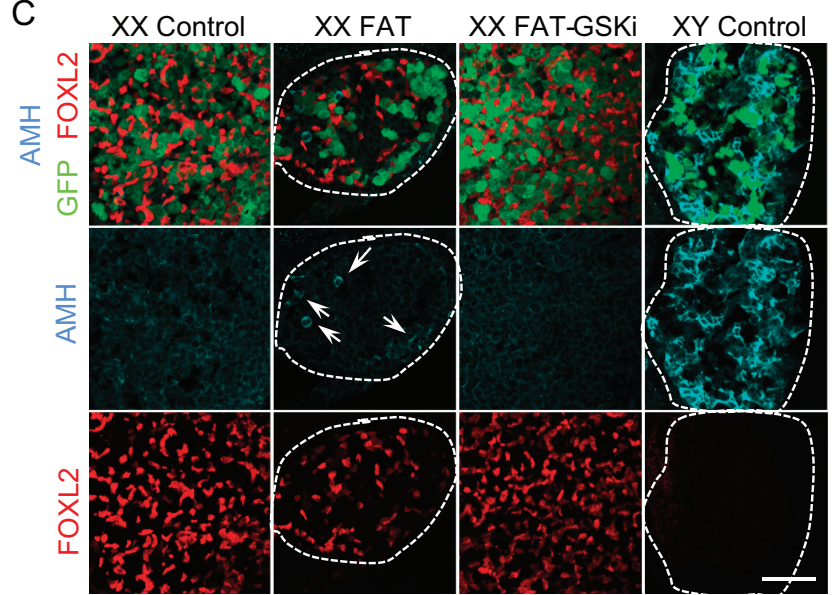

E11.5 gonad/mesonephros $+72 \mathrm{~h}$

D

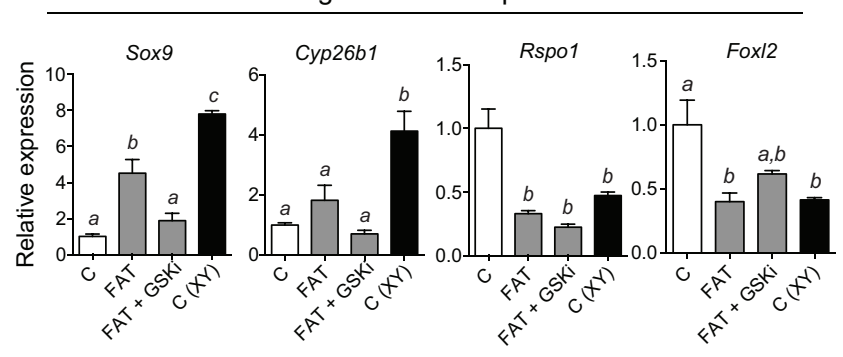

Figure 3 FAT induced testicular characteristics in E11.5 XX cultured gonads, while potentiating $\beta$-catenin prevented these effects. (A-C) IF images of E11.5 XX (and XY control) gonad/mesonephros tissues cultured for $72 \mathrm{~h}$ with control, FAT or FAT-GSKi media and analysed with antibodies specific for (A) laminin (cyan) and DPPA4 (red); (B) germ cells (GFP), SOX9 (cyan); (C) AMH (cyan) and FOXL2 (red). Arrowheads indicate SOX9-positive cells (B) and arrows indicate AMH-positive cells (C). Germ cells are marked by Oct4-GFP. Dashed white lines outline testis cord-like structures in XX gonads treated with FAT and testis cords in XY gonads. Scale bars: $50 \mu \mathrm{m}$. (D) qRT-PCR analysis of Sox9, Cyp26b1, Fox/2 and Rspo1 expression in E11.5 XX (and XY control; C (XY)) gonad/mesonephros tissues cultured for $72 \mathrm{~h}$ with control (C), FAT or FAT-GSKi media. Expression is relative to the XX control sample set at 1.0, normalised against Mapk1, Sdha and Canx. a, b and c are statistically different (ANOVA with multiple comparison test; $P<0.05$ ). Values are expressed as average \pm S.E.M., $n \geq 3$.

between the FAT and the XX control samples (Fig. 3D). However, GSKi did not rescue Rspo1 transcription or prevent FAT induction of Inhba (Fig. 3D and Supplementary Fig. 2B respectively).

\section{FAT promoted testicular characteristics more effectively in E11.5 XX gonads than in E12.5 XX gonads}

Testis determination occurs within a critical developmental window through the onset of Sry and Sox9 expression at E11.5. To determine whether testicular features could be promoted after E11.5, E12.5 XX gonad/mesonephros samples were cultured in control, FAT or FAT-GSKi media for $72 \mathrm{~h}$. Culture of gonad/mesonephros samples for $72 \mathrm{~h}$ with FAT induced Sox 9 and Cyp26b1 and repressed Fox/2 and Rspo 1 transcription with similar efficiency to that observed in E11.5 XX gonads (Supplementary Fig. 2D). Similarly, GSKi blocked the ability of FAT to induce Sox9 and Cyp26b1, but did not rescue expression of Fox/2 or
Rspo1 (Supplementary Fig. 2D). However, IF analysis of E12.5 gonad/mesonephros samples cultured with FAT revealed very limited laminin organisation around germ cells, and neither SOX9+ nor AMH+ cells were detected in E12.5 gonad/mesonephros samples treated with FAT (not shown).

\section{FGF9 and FAT induced expression of male germ line markers in XX gonads}

Somatic cell signalling in the developing testis induces male germ line development, which is marked by the transcription of male germ line genes such as Nanos 2 and Piwil2, strong nuclear localisation of DPPA4 protein and germ cell entry into mitotic arrest. By contrast, germ cells in XX gonads are characterised by expression of Stra8, distinctive nuclear localisation of phosphorylated $\mathrm{H} 2 \mathrm{AX}(\gamma \mathrm{H} 2 \mathrm{AX})$ and entry into meiosis.

To determine the effects of growth factors on germ cell development, E11.5 and E12.5 XX gonads were 
treated with FGF9, FAT, FAT-GSKi or control media for $72 \mathrm{~h}$. Although Nanos 2 remained below detection levels, Piwil2 and Dppa4 transcription tended towards higher levels in E11.5 gonads treated with FGF9 or FAT for $72 \mathrm{~h}$ (Fig. 4A). Piwil2 and Nanos2 were significantly increased in E12.5 XX gonads treated for $72 \mathrm{~h}$ with FGF9 or FAT (Fig. 4A). Moreover, culture of E11.5 XY male gonad/mesonephros samples with FAT for $72 \mathrm{~h}$ also increased transcription of Nanos2, Piwil2 and Dppa4 (Supplementary Fig. 3). In addition, quantitative flow cytometric analyses demonstrated significantly increased levels of DPPA4 protein in germ cells of E11.5 XX gonad/mesonephros samples treated with FGF9 and FAT (Fig. 4B). Significantly, germ cells in E11.5 XX FAT-treated samples were also associated with rare $\mathrm{AMH}$-positive cells indicating their localisation within testicular-like tissue (Figs 3C and 4C). Although the inclusion of GSKi only moderately affected Piwil2 expression in XX gonads treated with FAT, GSKi blocked the ability of FAT to increase Nanos2 and Dppa4 transcription (Figs 4A and 3B). Moreover, GSKi prevented FAT induction of DPPA4 protein expression as assessed using flow cytometry (Fig. 4B). Interestingly, DPPA4 protein levels were not significantly increased by $72 \mathrm{~h}$ of FGF9 or FAT treatment in E12.5 XX gonad/mesonephros, although a trend towards higher levels was observed, and these increases were blocked by GSKi (Fig. 4B).

FGF9 and FAT also modulated transcription and translation of STRA8. Stra8 transcription was reduced four-fold in E11.5 and E12.5 XX gonad/mesonephros samples treated with FGF9 (unpaired $t$-tests; $P<0.001$ and $P<0.0001$ respectively), but $S$ tra 8 was maintained at $\mathrm{XX}$ control levels in FAT- and FAT-GSKi-treated samples cultured from E11.5 and from E12.5 for $72 \mathrm{~h}$ (Fig. 4A). Despite this, quantitative flow cytometric analysis demonstrated that STRA8 protein was reduced to $\mathrm{XY}$ control levels in germ cells of E11.5 and E12.5 samples treated with either FGF9 or FAT (Fig. 4B). Moreover, the

A

E11.5 XX gonad and mesonephros $+72 \mathrm{~h}$

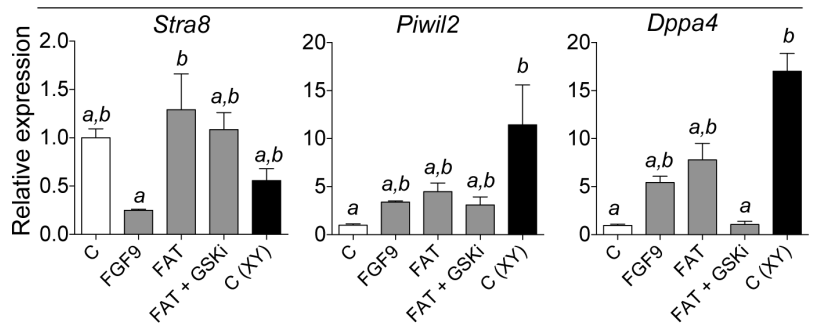

E12.5 XX gonad and mesonephros $+72 \mathrm{~h}$

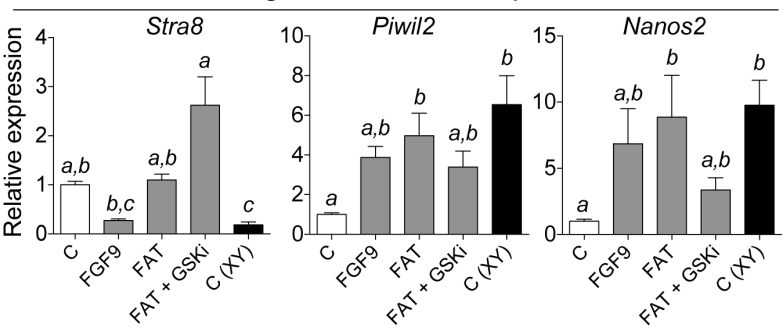

B
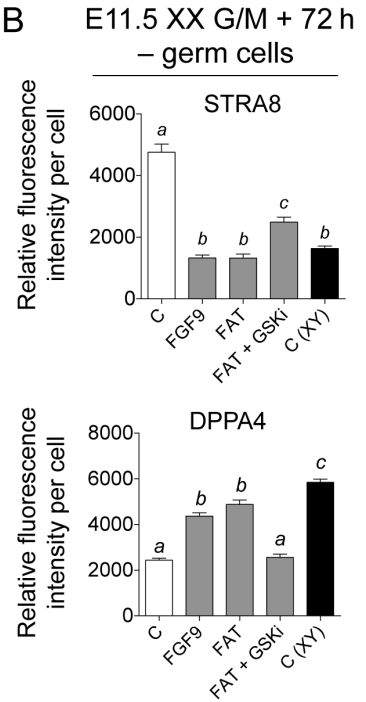

$\mathrm{E} 12.5 \mathrm{XX} \mathrm{G/M}+72 \mathrm{~h}$
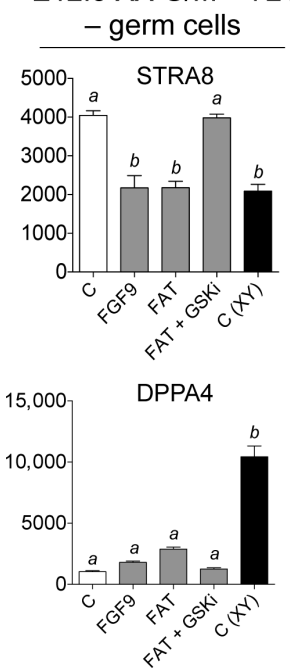

C

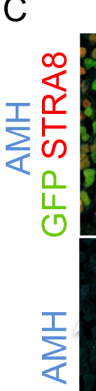

XX Control XX FAT XX FAT-GSKi XY Control

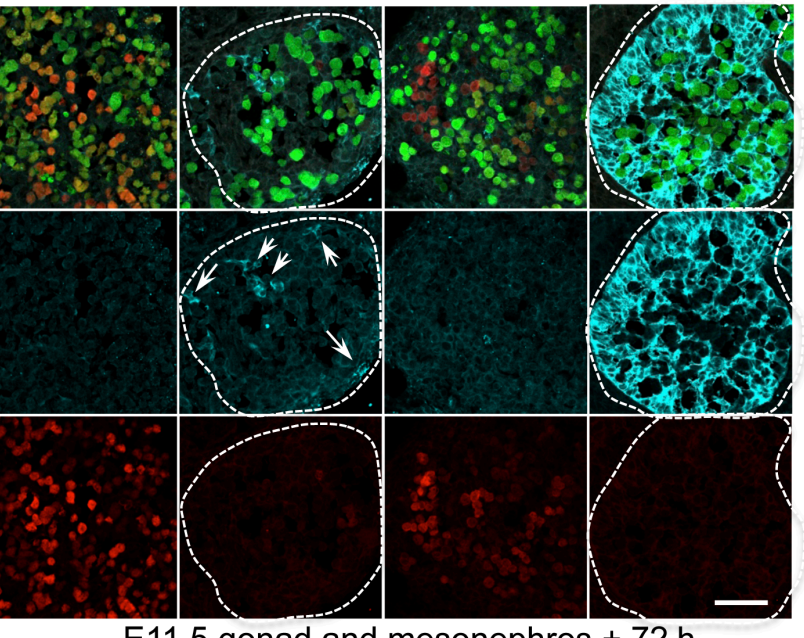

E11.5 gonad and mesonephros $+72 \mathrm{~h}$

Figure 4 FGF9 and FAT promoted male germ cell characteristics in XX germ cells. (A) qRT-PCR analysis of Dppa4 (E11.5 only), Stra8, Piwil2 (E11.5 and E12.5) and Nanos2 (E12.5 only) expression in XX (and XY control) gonad/mesonephros tissues cultured for $72 \mathrm{~h}$ with control (C), FGF9, FAT or FAT-GSKi media. Expression is relative to the XX control sample set at 1.0, normalised against Mvh (Ddx4) to correct for germ cell number in each sample. $a, b$ and $c$ are statistically different (ANOVA with multiple comparison test; $P<0.05$ ). Values are expressed as average \pm S.E.M., $n=3-6$. (B) Quantitative flow cytometric analysis of DPPA4 and STRA8 levels in Oct4-GFP-positive germ cells of E11.5 and E12.5 XX (and XY control) gonad/mesonephros sample tissues cultured for $72 \mathrm{~h}$ with control, FGF9, FAT or FAT-GSKi media. a, b and c are statistically different (ANOVA with multiple comparison test; $P<0.05$, values are expressed as average \pm S.E.M.; $n=3-8$ ). (C) IF images of E11.5 XX (and XY control) gonad/mesonephros tissues cultured for $72 \mathrm{~h}$ with control, FAT or FAT-GSKi media and analysed with antibodies specific for AMH (cyan) and STRA8 (red). Arrows indicate AMH-positive cells. Germ cells are marked by Oct4-GFP. Dashed white lines outline testis cord-like structures in XX gonads treated with FAT and testis cords in XY gonads. Scale bar: $50 \mu \mathrm{m}$. 
ability of FGF9 and FAT to repress STRA8 protein levels was partially alleviated by GSKi in E11.5 samples and completely abolished in E12.5 samples cultured for $72 \mathrm{~h}$ (Fig. 4B). These data were supported by IF analyses of STRA8 in gonad/mesonephros samples cultured under the same conditions (Fig. 4C).

\section{FGF9 induced mitotic arrest in XX germ cells}

Combined, these data indicated that FGF9 and FAT blocked germ cell entry into meiosis and promoted expression of male germ line markers in both $X X$ and $X Y$ gonads, whereas enhanced $\beta$-catenin signalling opposed these outcomes. However, definitive cell biological markers of male and female germ line development are the entry of germ cells into mitotic arrest at $G_{0} / G_{1}$, and meiosis at $G_{2} / M$ of the cell cycle respectively. To determine the relative abilities of FGF9 and FAT to regulate meiosis and mitotic arrest in germ cells, we extended treatment of E11.5 gonad/mesonephros samples to 96 and $120 \mathrm{~h}$. We used flow cytometry to separate germ cells based on their expression of $\mathrm{MVH}$ and measured cell cycle state based on DNA content using propidium iodide staining and proliferation based on EdU incorporation. In addition, we used flow cytometry to measure the percentage of germ cells that were positive for $\gamma \mathrm{H} 2 \mathrm{AX}$, which is highly enriched in meiotic germ cells.

In E11.5 XY gonad/mesonephros samples cultured in control media for $96 \mathrm{~h}, 78 \%$ of germ cells were in $\mathrm{G}_{0} / \mathrm{G}_{1}$, whereas $9 \%$ were in $\mathrm{G}_{2} / \mathrm{M}$ (Fig. $5 \mathrm{~A}$ i and ii), and this did not change after $120 \mathrm{~h}$ of culture (Fig. 5B i and ii). By comparison, in XX control gonads, $66 \%$ of germ cells were in $\mathrm{G}_{2} / \mathrm{M}$ by $120 \mathrm{~h}$ and $66 \%$ were positive for $\gamma \mathrm{H} 2 \mathrm{AX}$ (Fig. 5B ii and iii). Combined, these data demonstrate that germ cells in $X Y$ and $X X$ control gonads entered mitotic arrest or meiosis respectively, although with a slight delay compared with germ cells in vivo.

In XX gonads cultured with FGF9, 28\% of germ cells were in $\mathrm{G}_{0} / \mathrm{G}_{1}$ after $96 \mathrm{~h}$ (Fig. $5 \mathrm{~A}$ i), whereas $49 \%$ were
A E11.5 XX G/M germ cells + $96 \mathrm{~h}$

i.

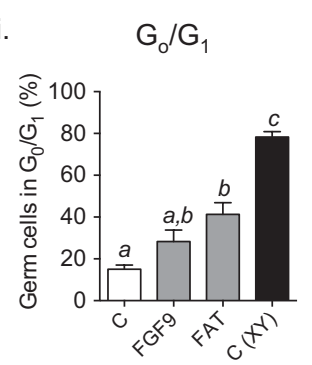

ii.

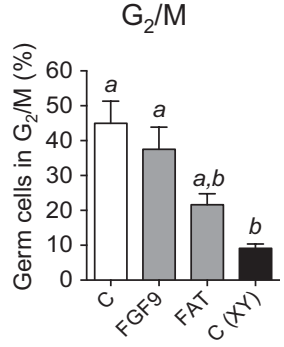

C

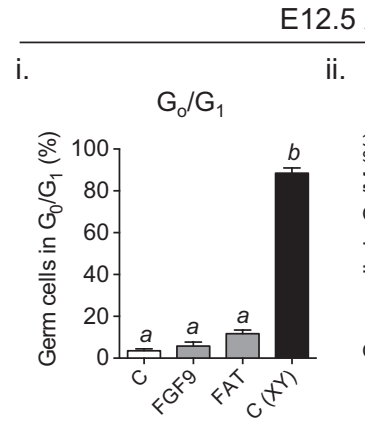

E12.5 XX G/M germ cells $+96 h$

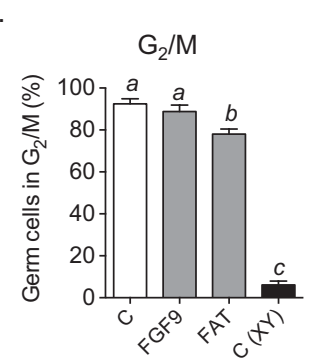

B

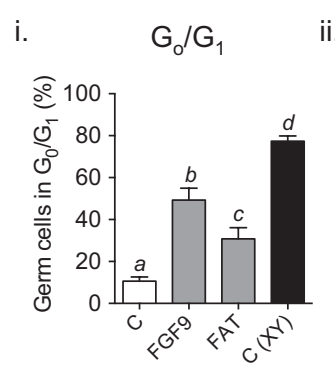

E11.5 XX G/M germ cells $+120 \mathrm{~h}$ ii.

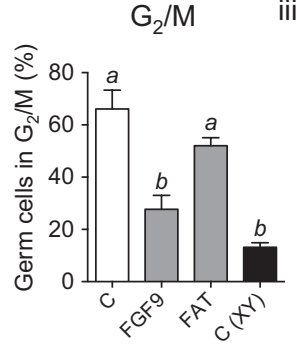

iii.

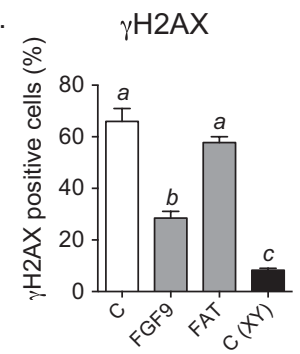

D

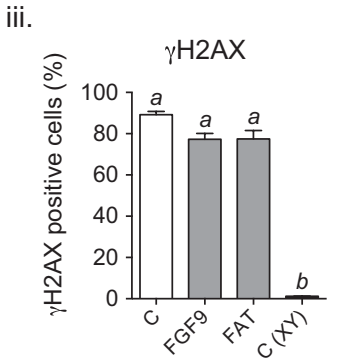

D $\quad E 12.5 X X G / M+72 h$

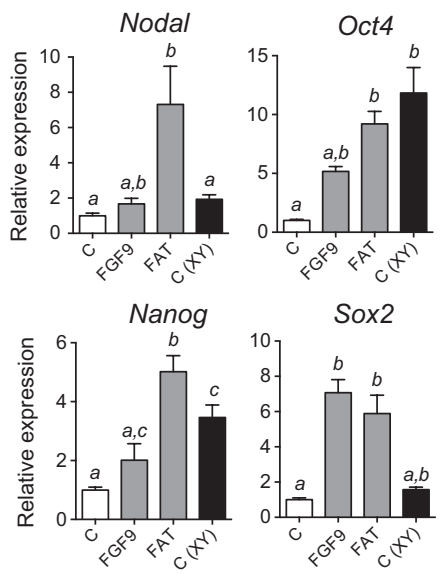

Figure 5 FGF9 induced mitotic arrest, whereas FAT maintained pluripotent gene expression in foetal germ cells. (A-C). Flow analysis of germ cells in $\mathrm{G}_{0} / \mathrm{G}_{1}$ and $\mathrm{G}_{2} / \mathrm{M}$ of the cell cycle and germ cells enriched for $\gamma \mathrm{H} 2 \mathrm{AX}$ in E11.5 and E12.5 XX and XY (control only; C (XY)) gonad/ mesonephros tissues cultured for 96 or $120 \mathrm{~h}$ with control (C), FGF9 or FAT media. A. E11.5 $+96 \mathrm{~h}$ culture $(\gamma \mathrm{H} 2 \mathrm{AX}$ not analysed); B. E11.5 +120h C. E12.5+96h. a, b, c and d are statistically different (ANOVA with multiple comparison test; $P<0.05$; values are expressed as average \pm S.E.M.; $n=6$ for $96 \mathrm{~h}, n=4$ for 120 h). (D) qRT-PCR analysis of Nodal, Oct4, Nanog and Sox2 expression in E12.5 XX (and XY control) gonad/mesonephros tissues cultured for $72 \mathrm{~h}$ with control (C), FGF9 or FAT media. Expression is relative to the XX control sample set at 1.0, normalised against Mvh $(D d x 4)$ to correct for germ cell number in each sample. $\mathrm{a}, \mathrm{b}$ and $\mathrm{c}$ are statistically different (ANOVA with multiple comparison test; $P<0.05$; values are expressed as average \pm S.E.M., $n \geq 3$ ). 
in $\mathrm{G}_{0} / \mathrm{G}_{1}$ after $120 \mathrm{~h}$ (Fig. 5B i), indicating that FGF9 promoted entry of $\mathrm{XX}$ germ cells into mitotic arrest with around two-thirds of the efficiency, and a slight delay compared with $\mathrm{XY}$ controls. By comparison, in FAT-treated samples $41 \%$ of germ cells were in $\mathrm{G}_{0} / \mathrm{G}_{1}$ at $96 \mathrm{~h}$ (Fig. $5 \mathrm{~A} \mathrm{i}$ ), but this dropped to $31 \%$ at $120 \mathrm{~h}$ (Fig. 5B i). Consistent with these findings, treatment of XX gonad/mesonephros tissues with FGF9 for $120 \mathrm{~h}$ reduced the percentage of germ cells in $\mathrm{G}_{2} / \mathrm{M}$ and the percentage expressing $\gamma \mathrm{H} 2 \mathrm{AX}$ (Fig. 5B ii, iii). However, neither the percentage of $X X$ germ cells in $\mathrm{G}_{2} / \mathrm{M}$ nor the proportion of $\gamma \mathrm{H} 2 \mathrm{AX}+$ cells decreased in the presence of FAT after $120 \mathrm{~h}$ of culture (Fig. 5B ii, iii). Combined, these data indicate that continued culture with FGF9 is more effective than FAT at inducing germ cells into $\mathrm{G}_{0} / \mathrm{G}_{1}$ arrest.

Although FAT treatment induced very limited morphological change in E12.5 XX gonads, transcription of the male somatic and germ line genes increased and ovarian markers decreased. Therefore, we next tested whether FGF9 or FAT altered the balance of mitotic arrest and meiosis in gonad/mesonephros samples cultured for $96 \mathrm{~h}$ from E12.5. As expected, germ cells entered mitotic arrest and meiosis with high efficiency in $X Y$ and $X X$ control-treated samples, with 89 and $92 \%$ in $G_{0} / G_{1}$ and $\mathrm{G}_{2} / \mathrm{M}$ respectively (Fig. $5 \mathrm{C} \mathrm{i,} \mathrm{ii).} \mathrm{Compared} \mathrm{with} \mathrm{E11.5,}$ the ability of FGF9 to block germ cell entry into meiosis was lost in $\mathrm{E} 12.5 \mathrm{XX}$ gonad/mesonephros samples, with $93 \%$ of germ cells in $\mathrm{G}_{2} / \mathrm{M}$ and $3.6 \%$ in $\mathrm{G}_{0} / \mathrm{G}_{1}$ after 96h (Fig. 5C). However, the proportion of germ cells in $\mathrm{G}_{2} / \mathrm{M}$ was moderately reduced in FAT-treated samples compared with XX controls (Fig. 5C ii), although the percentage of germ cells expressing $\gamma \mathrm{H} 2 \mathrm{AX}$ in FAT, FGF9 and XX control samples was similar (Fig. 5C iii).

\section{FAT maintained expression of the core pluripotency genes in germ cells}

The core network regulating pluripotency is repressed between E13.5 and E15.5 in both XX and XY germ cells, although Nanog is maintained for a day longer in $X Y$ compared with XX germ cells. Nodal is expressed in XY germ cells during this period and has been implicated in maintaining pluripotency. Therefore, we used qRT-PCR to determine whether FGF9, FAT and FAT-GSKi modulated expression of Nodal, Oct4, Sox2 and Nanog in E12.5 XX gonads treated for $72 \mathrm{~h}$. Transcription of Nodal, Sox 2 and Nanog was higher in E12.5 XX gonads treated with FAT for $72 \mathrm{~h}$ than in $X X$ and $X Y$ control samples (Fig. 5D). In FGF9-treated samples, transcription of Nodal was similar to that in $X X$ and $X Y$ controls, whereas Oct4 and Nanog were transcribed at intermediate levels, and Sox2 was transcribed at high levels (Fig. 5D). Similarly, increased expression of Nodal, Nanog and Oct4 was detected in E11.5 XY gonad/mesonephros samples treated with FAT, but not FGF9, TGF $\beta$ or activin alone for $72 \mathrm{~h}$ (Supplementary Fig. 4).

\section{Discussion}

\section{Growth factors FGF9, activin and TGF $\beta$ promote testicular characteristics in $X X$ gonads}

In this study, we have demonstrated that both FGF9 and, to a more limited extent, TGF $\beta$, promote proliferation of supporting cells in XX gonads but activin alone did not. In addition, we provided evidence that culture of $X X$ gonads with FGF9, activin and TGF $\beta$ repressed ovarian development and induced transcription of Sox9 and limited expression of SOX9 protein. This was associated with FAT-induced formation of laminin-delineated cords that were morphologically similar to early testis cords. Moreover, FGF9 and FAT directly or indirectly blocked female germ line development while promoting male germ line development, and FAT maintained high levels of germ cell pluripotency. The testis-promoting activity of FAT was significantly reduced by blocking GSK, consistent with a role for $\beta$-catenin signalling in opposing the activity of FAT in this context. Although FGF9 was less effective at inducing testis development than FAT, it was moderately more effective at blocking meiosis and promoting mitotic arrest in XX germ cells and did not maintain germ line pluripotency to the same extent as FAT. Together, these data identified a cooperative role for FGF9, activin and TGF $\beta$ in inducing testicular characteristics in cultured XX gonads.

Gene knockout studies have demonstrated that FGF9 signalling is essential for testis development, but deletion of activin or TGF $\beta$ genes have relatively mild effects (Shull et al. 1992, Colvin et al. 2001, Schmahl et al. 2004, Kim et al. 2006, 2007, Bagheri-Fam et al. 2008, Memon et al. 2008, Archambeault \& Yao 2010, Moreno et al. 2010, Mendis et al. 2011). Consistent with this, this study demonstrated that ex vivo exposure of $\mathrm{XX}$ gonads to FGF9 promoted changes in XX gonad characteristic of the developing testis, including supporting cell proliferation, repression of ovarian genes and promotion of male germ line development. However, FGF9 alone was insufficient to drive Sox9 transcription or the formation of laminin-delineated testis cords to the extent achieved with FAT, demonstrating a significant contribution from activin and TGF $\beta$. This is consistent with a previous study in which intact foetal gonads were exposed to FGF9 in ex vivo cultures (Schmahl \& Capel 2003), although FGF9 alone was capable of inducing SOX9 in dissociated gonadal cells or at the periphery of XX gonads when exposed to FGF9-coated beads (Kim et al. 2006).

Several factors may explain the ability of FGF9 to induce SOX9 in dissociated gonadal cells or in cells close to FGF9 coated beads, but not in whole gonads. One possibility is that $\beta$-catenin signalling is dispersed in dissociated cells or is less effective at the gonadal periphery, but remains intact in whole gonads. Alternatively, FGF9 levels may be insufficiently increased in whole gonad cultures exposed to FGF9 in 
the medium compared with local FGF9 levels achieved using beads. Nonetheless, activin and TGF $\beta$ contributed to the induction of Sox9 when applied in combination with FGF9, although they were also individually insufficient to induce Sox9 expression or testis development in cultured XX gonads. Combined, these data indicate that FGF9, activin and TGF $\beta$ act together to promote Sox9 transcription and some testicular characteristics in intact cultured XX gonads and limited expression of SOX9 and AMH protein. This conclusion is consistent with previous observations that activin/ TGF $\beta$ signalling is required for testis cord formation and Sertoli cell proliferation in E11.5-E12.5 XY gonads (Miles et al. 2013) and the established role for FGF9 in testis development (Lin \& Capel 2015).

Although we observed increased Sox9, Cyp26b1 and Inhba transcription and some SOX9+ and $\mathrm{AMH}+$ cells in FAT-treated XX gonads, Dhh was not upregulated, indicating that Sertoli cell development was restricted in this system. Similarly, while SOX9+ and AMH+ cells were detected, their numbers were low, also indicating that Sertoli cell differentiation was limited. This presumably explains why Amh transcription was not increased when the whole gonad/mesonephros cell population was analysed using qRT-PCR. Together, these observations indicate that although FAT induced some testicular characteristics in XX gonads, the extent of testicular development was limited.

\section{A role for TGF $\beta$ and activin in testis organisation?}

One of the more prominent features induced by FAT was the substantial morphological reorganisation of gonadal cells characterised by aggregation of germ cells with supporting cells in laminin-delineated structures similar to testis cords. These morphological changes could occur via the supporting cells, as they proliferate and differentiate into Sertoli-like cells and drive cellular reorganisation, or could be driven by growth factorstimulated cell reorganisation and basement membrane deposition and/or organisation. However, cellular and basement membrane organisations were strongly affected by FAT, whereas Sertoli cell differentiation was incomplete. It therefore seems likely that FGF9, activin and TGF $\beta$ actively support cord formation through enhanced deposition and/or organisation of basement membrane, rather than indirectly through extensive Sertoli cell differentiation. Consistent with this, TGF $\beta$ and activin have been associated with basement membrane deposition in other systems (Whiting et al. 2003, Krag et al. 2007, Botta et al. 2012). Cord formation is also likely to involve supporting cell proliferation, which was driven in XX gonads treated with either FGF9 or FAT at levels equivalent to Sertoli cell proliferation in XY gonads. Moreover, TGF $\beta$ also promoted supporting cell proliferation in $\mathrm{XX}$ gonads, albeit with less potency than FGF9. However, as FGF9 was sufficient to drive maximal supporting cell proliferation but not extensive deposition of laminin, supporting cell proliferation per se appears insufficient to account for the presence of testis cords in FAT-treated XX gonads.

\section{Enhancing $\beta$-catenin moderates the testis-promoting activity of FGF9, activin and TGF $\beta$}

It is well established that WNT4/ $\beta$-catenin signalling opposes activity of the testis-determining pathway, favouring ovarian development (Chassot et al. 2014). In this study, blocking GSK abolished the ability of FGF9 and FAT to induce expression of Sox9 and Cyp26b1; however, expression of the ovary-promoting gene Rspo1 was not restored, and Foxl2 transcription was only partially restored. The failure to restore Rspo 1 is perhaps not surprising as GSK phosphorylation of $\beta$-catenin occurs downstream of RSPO1. However, the factors limiting the ability of GSKi to fully restore Fox 2 transcription remain unclear.

Interestingly, the foetal Leydig cell-expressed gene Inhba was strongly induced by FAT but was not suppressed by blocking GSKi, indicating that this pathway is not subject to repression by $\beta$-catenin. Consistent with the ability of $\beta$-catenin to inhibit testis development, GSKi also blocked the formation of laminin-delineated testis cords and the occurrence of SOX9 and AMH-positive cells in E11.5 gonads treated with FAT. However, in a related study, blocking GSK in XX foetal gonads increased supporting cell proliferation in the presence of FGF9 (Gustin et al. 2016). Taken together, these observations indicate that although $\beta$-catenin blocks FAT induction of testis development, it does so by blocking growth factor induction of testis differentiation genes rather than restricting supporting cell proliferation.

\section{FGF9 promotes male germ line differentiation and germ cell mitotic arrest within a critical window between E11.5 and E12.5}

Sex-specific development of germ cells is dependent on the surrounding somatic cell environment. This is achieved in part by FGF9, which represses germ cell expression of Stra8 and entry into meiosis, while promoting expression of male germ line markers, including Nanos2 (Barrios et al. 2010, Bowles et al. 2010, Wu et al. 2013). However, TGF $\beta /$ activin signalling is also directly or indirectly required for male germ line development (Miles et al. 2013, Wu et al. 2013). Consistent with this, treatment of E11.5 XX gonad/mesonephros samples with FGF9 or FAT increased expression of the male germ cell-expressed genes Nanos2, Piwil2 and Dppa4 and high levels of DPPA4 protein.

Although FGF9 can reduce Stra8 transcription and entry of germ cells into meiosis (Bowles et al. 2010), 
the ability of FGF9 to promote germ cell mitotic arrest has not been studied. In this study, flow cytometric analyses demonstrated a greater proportion of germ cells in $\mathrm{G}_{0} / \mathrm{G}_{1}$ in $\mathrm{XX}$ gonads treated with FGF9 from E11.5 than in either XX controls or FAT-treated samples, consistent with a role for FGF9 in promoting germ cell mitotic arrest. Moreover, the percentage of germ cells expressing $\gamma \mathrm{H} 2 \mathrm{AX}$ was significantly lower in FGF9treated gonads than in XX control gonads. Despite this, the ability of FGF9 to induce mitotic arrest in foetal germ cells was lost when gonad/mesonephros samples were cultured from E12.5, demonstrating that FGF9 primarily induces mitotic arrest in XX germ cells in the critical window between E11.5 and E12.5, corresponding to the male sex-determining period for XY germ cells (Adams \& McLaren 2002).

Interestingly, although FGF9 reduced Stra8 transcription in XX germ cells, FAT failed to do so, indicating that activin/TGF $\beta$ signalling negates the ability of FGF9 to transcriptionally repress Stra8. Despite this, both FGF9 and FAT reduced STRA8 protein expression as assessed by quantitative flow cytometry and IF, indicating that control of STRA8 activity is achieved at both the transcriptional and translational levels. However, although FAT reduced STRA8 protein with efficiency similar to FGF9, the percentage of germ cells in $\mathrm{G}_{2} / \mathrm{M}$ and expressing $\gamma \mathrm{H} 2 \mathrm{AX}$ was only partly reduced in FAT-treated samples. This is perplexing as it indicates that germ cells enter meiosis in the absence of STRA8 in FAT-treated samples. Nevertheless, as Stra8 transcription remained high in FAT-treated samples, it is possible that sufficient protein persisted during the earlier stages of FAT-treated cultures to enable germ cell entry into meiosis.

\section{FAT enhances germ line pluripotency}

Despite the greater ability of FAT to promote testicular development at the somatic level, with the exception of inducing mitotic arrest and blocking entry into meiosis, FGF9 and FAT appeared to promote male development in XX germ cells with similar efficiency. Although, FAT induced mitotic arrest in germ cells more effectively than FGF9 in XX gonads treated from E11.5 for $96 \mathrm{~h}$, this pattern was reversed in XX gonads treated for $120 \mathrm{~h}$. It remains unclear why fewer germ cells were induced into $G_{0} / G_{1}$ in $E 11.5$ samples treated with $F A T$, but one possibility is that continued exposure to FAT maintains germ cells in a relatively undifferentiated state and causes arresting germ cells to re-initiate proliferation. Consistent with this, transcription of Nodal, Nanog and Oct4 was maintained at higher levels in XX samples treated for $72 \mathrm{~h}$ with FAT than FGF9 or control media. It therefore appears that activin and/or TGF $\beta$ contribute significantly to maintaining germ cell pluripotency, a conclusion consistent with observed roles for
activin/TGF $\beta /$ Nodal signalling in maintaining Nanog expression and pluripotency in $\mathrm{XY}$ germ cells (Spiller et al. 2012, Miles et al. 2013), the epiblast and in human embryonic stem cells (Mesnard et al. 2006, Vallier et al. 2009). However, it also seems likely that activin/TGF $\beta$ interact with FGF signalling to maintain pluripotency, as FGF9 can promote derivation of pluripotent EG cells (Durcova-Hills et al. 2006), and in this study, FGF9 alone was sufficient to partially maintain germ cell pluripotency in XX germ cells. Moreover, FAT increased transcription of pluripotency genes in $\mathrm{XX}$ samples treated for $72 \mathrm{~h}$, whereas individual treatments using FGF9, activin and TGF $\beta$ had no effect.

Pluripotency is normally repressed in the developing germ line and maintained during formation of germ cell tumours, consistent with a requirement to downregulate pluripotency genes to allow germ line differentiation (Cook et al. 2009, Krentz et al. 2009, Western 2009, Western et al. 2010). Fgf9 is repressed in the developing testis between E12.5 and E14.5 (Bowles et al. 2010, Miles et al. 2013), indicating that continued exposure may be detrimental for germ line development. However, in vivo regulation of Fgf9 differs from that of Inhba (Activin A) and TGF $\beta$ in that, Inhba increases in somatic cells, while TGF $\beta 1$ is upregulated in the germ cells of the developing testis between E12.5 and E15.5 (Miles et al. 2013). Moreover, FAT and FGF9 also induced male development in XX germ cells, consistent with observed roles for FGF9 and activin in promoting male germ line differentiation (Bowles et al. 2010, Wu et al. 2013). Taken together, these observations indicate that FGF9, TGF $\beta$ and activin act in a complex network that regulates both differentiation and pluripotency in foetal germ cells, and the balance of these factors is critical for ensuring appropriate male germ line development.

\section{Conclusions}

Male sex determination is centrally dependent on the transcription factors SRY and SOX9, which activate signalling pathways involved in testis differentiation. By demonstrating that FGF9, activin and TGF $\beta$ can partly initiate testis development, this study provides insight into the complex inductive processes underpinning sex determination and early gonad differentiation in mice. Male sex determination is considered to involve transition across a 'threshold' after which testis development is ensured. Growth factors provide an attractive mechanism through which the male sexdetermining threshold may be achieved. Moreover, activity of FGF9, activin and TGF $\beta$ is modulated by ovarian factors such as $\beta$-catenin, potentially enhancing dosage-responsive outcomes. This may be of particular relevance for understanding reproductive disorders in patients in whom gonadal environment may be altered 
during development, leading to partially disrupted gonad differentiation, reduced fertility and/or germ cell tumours (Skakkebaek et al. 2001). In addition, signalling mechanisms involving the FGF, activin/ TGF $\beta$ and $\beta$-catenin pathways are highly conserved between species and are broadly used to modulate developmental processes. It is interesting to speculate that similar signalling mechanisms may regulate gonad development in a broad range of situations, particularly non-mammalian species in which sex is determined through genetic or environmental mechanisms not involving Sry.

\section{Supplementary data}

This is linked to the online version of the paper at http://dx.doi. org/10.1530/REP-16-0293.

\section{Declaration of interest}

The authors declare that there is no conflict of interest that could be perceived as prejudicing the impartiality of the research reported.

\section{Funding}

This work was supported by funding from the Monash University Faculty of Medicine, Nursing and Health Sciences and NHMRC grants GNT1043939 and GNT1051223 to P W, the Victorian Government's Operational Infrastructure Support Program and an NHMRC Program grant awarded to A S.

\section{Acknowledgements}

The authors thank Dagmar Wilhelm for the FOXL2 antibody, Nicolle Gibson and Laura Deans for support with animal work and Matt Burton for support with confocal imaging.

\section{References}

Adams IR \& McLaren A 2002 Sexually dimorphic development of mouse primordial germ cells: switching from oogenesis to spermatogenesis. Development 129 1155-1164.

Archambeault DR \& Yao HH 2010 Activin A, a product of fetal Leydig cells, is a unique paracrine regulator of Sertoli cell proliferation and fetal testis cord expansion. PNAS 107 10526-10531. (doi:10.1073/ pnas.1000318107)

Bagheri-Fam S, Sim H, Bernard P, Jayakody I, Taketo MM, Scherer G \& Harley VR 2008 Loss of Fgfr2 leads to partial XY sex reversal. Developmental Biology 314 71-83. (doi:10.1016/j. ydbio.2007.11.010)

Baltus AE, Menke DB, Hu YC, Goodheart ML, Carpenter AE, de Rooij DG \& Page DC 2006 In germ cells of mouse embryonic ovaries, the decision to enter meiosis precedes premeiotic DNA replication. Nature Genetics 38 1430-1434. (doi:10.1038/ng1919)

Barrios F, Filipponi D, Pellegrini M, Paronetto MP, Di Siena S, Geremia R, Rossi P, De Felici M, Jannini EA \& Dolci S 2010 Opposing effects of retinoic acid and FGF9 on Nanos2 expression and meiotic entry of mouse germ cells. Journal of Cell Science 123 871-880. (doi:10.1242/ jcs.057968)
Behringer RR, Finegold MJ \& Cate RL 1994 Müllerian-inhibiting substance function during mammalian sexual development. Cell 79 415-425. (doi:10.1016/0092-8674(94)90251-8)

Bennett CN, Ross SE, Longo KA, Bajnok L, Hemati N, Johnson KW, Harrison SD \& MacDougald OA 2002 Regulation of Wnt signaling during adipogenesis. Journal of Biological Chemistry 277 30998-31004. (doi:10.1074/jbc.M204527200)

Bernard P, Ryan J, Sim H, Czech DP, Sinclair AH, Koopman P \& Harley VR 2012 Wnt signaling in ovarian development inhibits Sf1 activation of Sox9 via the Tesco enhancer. Endocrinology 153 901-912. (doi:10.1210/ en.2011-1347)

Botta A, Delteil F, Mettouchi A, Vieira A, Estrach S, Negroni L, Stefani C, Lemichez E, Meneguzzi G \& Gagnoux-Palacios L 2012 Confluence switch signaling regulates ECM composition and the plasmin proteolytic cascade in keratinocytes. Journal of Cell Science 125 4241-4252. (doi:10.1242/jcs.096289)

Bowles J, Knight D, Smith C, Wilhelm D, Richman J, Mamiya S, Yashiro K, Chawengsaksophak K, Wilson MJ, Rossant J et al. 2006 Retinoid signaling determines germ cell fate in mice. Science 312 596-600. (doi:10.1126/science.1125691)

Bowles J, Feng CW, Spiller C, Davidson TL, Jackson A \& Koopman P 2010 FGF9 suppresses meiosis and promotes male germ cell fate in mice. Developmental Cell 19 440-449. (doi:10.1016/j.devcel.2010.08.010)

Chassot AA, Ranc F, Gregoire EP, Roepers-Gajadien HL, Taketo MM, Camerino G, de Rooij DG, Schedl A \& Chaboissier MC 2008 Activation of beta-catenin signaling by Rspo1 controls differentiation of the mammalian ovary. Human Molecular Genetics 17 1264-1277. (doi:10.1093/hmg/ddn016)

Chassot AA, Gillot I \& Chaboissier MC 2014 R-spondin1, WNT4, and the CTNNB1 signaling pathway: strict control over ovarian differentiation. Reproduction 148 R97-110. (doi:10.1530/REP-14-0177)

Colvin JS, Green RP, Schmahl J, Capel B \& Ornitz DM 2001 Male-tofemale sex reversal in mice lacking fibroblast growth factor 9. Cell 104 875-889. (doi:10.1016/S0092-8674(01)00284-7)

Cook MS, Coveney D, Batchvarov I, Nadeau JH \& Capel B 2009 BAXmediated cell death affects early germ cell loss and incidence of testicular teratomas in Dnd1(Ter/Ter) mice. Developmental Biology 328 377-383. (doi:10.1016/j.ydbio.2009.01.041)

Crisponi L, Deiana M, Loi A, Chiappe F, Uda M, Amati P, Bisceglia L, Zelante L, Nagaraja R, Porcu S et al. 2001 The putative forkhead transcription factor FOXL2 is mutated in blepharophimosis/ptosis/ epicanthus inversus syndrome. Nature Genetics 27 159-166. (doi:10.1038/84781)

DiNapoli L, Batchvarov J \& Capel B 2006 FGF9 promotes survival of germ cells in the fetal testis. Development 133 1519-1527. (doi:10.1242/ dev.02303)

Durcova-Hills G, Adams IR, Barton SC, Surani MA \& McLaren A 2006 The role of exogenous fibroblast growth factor-2 on the reprogramming of primordial germ cells into pluripotent stem cells. Stem Cells $\mathbf{2 4}$ 1441-1449. (doi:10.1634/stemcells.2005-0424)

Garcia-Ortiz JE, Pelosi E, Omari S, Nedorezov T, Piao Y, Karmazin J, Uda M, Cao A, Cole SW, Forabosco A et al. 2009 Foxl2 functions in sex determination and histogenesis throughout mouse ovary development. BMC Developmental Biology 9 36. (doi:10.1186/1471-213X-9-36)

Gustin SE, Hogg K, Stringer JM, Rastetter RH, Pelosi E, Miles DC, Sinclair AH, Wilhelm D \& Western PS 2016 WNT/beta-catenin and p27/FOXL2 differentially regulate supporting cell proliferation in the developing ovary. Developmental Biology 412 250-260. (doi:10.1016/j. ydbio.2016.02.024)

Kim Y, Kobayashi A, Sekido R, DiNapoli L, Brennan J, Chaboissier MC, Poulat F, Behringer RR, Lovell-Badge R \& Capel B 2006 Fgf9 and Wnt4 act as antagonistic signals to regulate mammalian sex determination. PLoS Biology 4 e187. (doi:10.1371/journal.pbio.0040187)

Kim Y, Bingham N, Sekido R, Parker KL, Lovell-Badge R \& Capel B 2007 Fibroblast growth factor receptor 2 regulates proliferation and Sertoli differentiation during male sex determination. PNAS 104 16558-16563. (doi:10.1073/pnas.0702581104)

Kjartansdottir KR, Reda A, Panula S, Day K, Hultenby K, Soder O, Hovatta O \& Stukenborg JB 2015 A combination of culture conditions and gene expression analysis can be used to investigate and predict hES cell differentiation potential towards male gonadal cells. PLOS ONE 10 e0144029. (doi:10.1371/journal.pone.0144029) 
Kocer A, Reichmann J, Best D \& Adams IR 2009 Germ cell sex determination in mammals. Molecular Human Reproduction $\mathbf{1 5}$ 205-213. (doi:10.1093/molehr/gap008)

Koubova J, Menke DB, Zhou Q, Capel B, Griswold MD \& Page DC 2006 Retinoic acid regulates sex-specific timing of meiotic initiation in mice. PNAS 103 2474-2479. (doi:10.1073/pnas.0510813103)

Krag S, Nyengaard JR \& Wogensen L 2007 Combined effects of moderately elevated blood glucose and locally produced TGF-beta1 on glomerular morphology and renal collagen production. Nephrology Dialysis Transplantation 22 2485-2496. (doi:10.1093/ndt/gfm229)

Krentz AD, Murphy MW, Kim S, Cook MS, Capel B, Zhu R, Matin A, Sarver AL, Parker KL, Griswold MD et al. 2009 The DM domain protein DMRT1 is a dose-sensitive regulator of fetal germ cell proliferation and pluripotency. PNAS 106 22323-22328. (doi:10.1073/ pnas.0905431106)

Lin YT \& Capel B 2015 Cell fate commitment during mammalian sex determination. Current Opinion in Genetics \& Development 32 144-152. (doi:10.1016/j.gde.2015.03.003)

Livak KJ \& Schmittgen TD 2001 Analysis of relative gene expression data using real-time quantitative PCR and the 2(-Delta Delta C(T)) method. Methods 25 402-408. (doi:10.1006/meth.2001.1262)

Maatouk DM, DiNapoli L, Alvers A, Parker KL, Taketo MM \& Capel B 2008 Stabilization of beta-catenin in XY gonads causes male-to-female sexreversal. Human Molecular Genetics 17 2949-2955. (doi:10.1093/hmg/ ddn193)

McFarlane L, Truong V, Palmer JS \& Wilhelm D 2013 Novel PCR assay for determining the genetic sex of mice. Sexual Development 7 207-211. (doi:10.1159/000348677)

Memon MA, Anway MD, Covert TR, Uzumcu M \& Skinner MK 2008 Transforming growth factor beta (TGFbeta1, TGFbeta2 and TGFbeta3) null-mutant phenotypes in embryonic gonadal development. Molecular and Cellular Endocrinology 294 70-80. (doi:10.1016/j.mce.2008.08.017)

Mendis SH, Meachem SJ, Sarraj MA \& Loveland KL 2011 Activin A balances Sertoli and germ cell proliferation in the fetal mouse testis. Biology of Reproduction 84 379-391. (doi:10.1095/biolreprod.110.086231)

Mesnard D, Guzman-Ayala M \& Constam DB 2006 Nodal specifies embryonic visceral endoderm and sustains pluripotent cells in the epiblast before overt axial patterning. Development 133 2497-2505.

Miles DC, van den Bergen JA, Sinclair AH \& Western PS 2010 Regulation of the female mouse germ cell cycle during entry into meiosis. Cell Cycle 9 408-418. (doi:10.4161/cc.9.2.10691)

Miles DC, Wakeling SI, Stringer JM, van den Bergen JA, Wilhelm D, Sinclair AH \& Western PS 2013 Signaling through the TGF beta-activin receptors ALK4/5/7 regulates testis formation and male germ cell development. PLOS ONE 8 e54606. (doi:10.1371/journal.pone.0054606)

Moreno SG, Attali M, Allemand I, Messiaen S, Fouchet P, Coffigny H, Romeo PH \& Habert R 2010 TGFbeta signaling in male germ cells regulates gonocyte quiescence and fertility in mice. Developmental Biology 342 74-84. (doi:10.1016/j.ydbio.2010.03.007)

Mork L, Maatouk DM, McMahon JA, Guo JJ, Zhang P, McMahon AP \& Capel B 2012 Temporal differences in granulosa cell specification in the ovary reflect distinct follicle fates in mice. Biology of Reproduction $\mathbf{8 6}$ 37. (doi:10.1095/biolreprod.111.095208)

Naujok O, Lentes J, Diekmann U, Davenport C \& Lenzen S 2014 Cytotoxicity and activation of the Wnt/beta-catenin pathway in mouse embryonic stem cells treated with four GSK3 inhibitors. BMC Research Notes 7 273. (doi:10.1186/1756-0500-7-273)

Rastetter RH, Bernard P, Palmer JS, Chassot AA, Chen H, Western PS, Ramsay RG, Chaboissier MC \& Wilhelm D 2014 Marker genes identify three somatic cell types in the fetal mouse ovary. Developmental Biology 394 242-252. (doi:10.1016/j.ydbio.2014.08.013)

Rosairo D, Kuyznierewicz I, Findlay J \& Drummond A 2008 Transforming growth factor-beta: its role in ovarian follicle development. Reproduction 136 799-809. (doi:10.1530/REP-08-0310)

Schmahl J \& Capel B 2003 Cell proliferation is necessary for the determination of male fate in the gonad. Developmental Biology 258 264-276. (doi:10.1016/S0012-1606(03)00122-2)

Schmahl J, Kim Y, Colvin JS, Ornitz DM \& Capel B 2004 Fgf9 induces proliferation and nuclear localization of FGFR2 in Sertoli precursors during male sex determination. Development 131 3627-3636. (doi:10.1242/dev.01239)

Schmidt D, Ovitt CE, Anlag K, Fehsenfeld S, Gredsted L, Treier AC \& Treier M 2004 The murine winged-helix transcription factor Foxl2 is required for granulosa cell differentiation and ovary maintenance. Development 131 933-942. (doi:10.1242/dev.00969)

Shull MM, Ormsby I, Kier AB, Pawlowski S, Diebold RJ, Yin M, Allen R, Sidman C, Proetzel G, Calvin D et al. 1992 Targeted disruption of the mouse transforming growth factor-beta 1 gene results in multifocal inflammatory disease. Nature 359 693-699. (doi:10.1038/359693a0)

Skakkebaek NE, Rajpert-De Meyts E \& Main KM 2001 Testicular dysgenesis syndrome: an increasingly common developmental disorder with environmental aspects. Human Reproduction 16 972-978. (doi:10.1093/humrep/16.5.972)

Spiller CM, Wilhelm D \& Koopman P 2010 Retinoblastoma 1 protein modulates $X Y$ germ cell entry into $\mathrm{G} 1 / \mathrm{G} 0$ arrest during fetal development in mice. Biology of Reproduction 82 433-443. (doi:10.1095/ biolreprod.109.078691)

Spiller CM, Feng CW, Jackson A, Gillis AJ, Rolland AD, Looijenga LH, Koopman P \& Bowles J 2012 Endogenous nodal signaling regulates germ cell potency during mammalian testis development. Development 139 4123-4132. (doi:10.1242/dev.083006)

Suzuki A \& Saga Y 2008 Nanos2 suppresses meiosis and promotes male germ cell differentiation. Genes \& Development 22 430-435. (doi:10.1101/gad.1612708)

Szabo PE, Hubner K, Scholer H \& Mann JR 2002 Allele-specific expression of imprinted genes in mouse migratory primordial germ cells. Mechanisms of Development 115 157-160. (doi:10.1016/S09254773(02)00087-4)

Tepekoy F \& Akkoyunlu G 2016 The effect of FSH and activin A on Akt and MAPK1/3 phosphorylation in cultured bovine ovarian cortical strips. Journal of Ovarian Research 9 13. (doi:10.1186/s13048-0160222-2)

Tevosian SG 2014 Transgenic mouse models in the study of reproduction: insights into GATA protein function. Reproduction 148 R1-R14. (doi:10.1530/REP-14-0086)

Tomizuka K, Horikoshi K, Kitada R, Sugawara Y, Iba Y, Kojima A, Yoshitome A, Yamawaki K, Amagai M, Inoue A et al. 2008 R-spondin1 plays an essential role in ovarian development through positively regulating Wnt-4 signaling. Human Molecular Genetics 17 1278-1291. (doi:10.1093/hmg/ddn036)

Uda M, Ottolenghi C, Crisponi L, Garcia JE, Deiana M, Kimber W, Forabosco A, Cao A, Schlessinger D \& Pilia G 2004 Foxl2 disruption causes mouse ovarian failure by pervasive blockage of follicle development. Human Molecular Genetics 13 1171-1181. (doi:10.1093/ hmg/ddh124)

Vainio S, Heikkila M, Kispert A, Chin N \& McMahon AP 1999 Female development in mammals is regulated by Wnt-4 signalling. Nature 397 405-409. (doi:10.1038/17068)

Vallier L, Mendjan S, Brown S, Chng Z, Teo A, Smithers LE, Trotter MW, Cho CH, Martinez A, Rugg-Gunn P et al. 2009 Activin/Nodal signalling maintains pluripotency by controlling Nanog expression. Development 136 1339-1349. (doi:10.1242/dev.033951)

van den Bergen JA, Miles DC, Sinclair AH \& Western PS 2009 Normalizing gene expression levels in mouse fetal germ cells. Biology of Reproduction 81 362-370. (doi:10.1095/biolreprod.109.076224)

Wakeling SI, Miles DC \& Western PS 2013 Identifying disruptors of male germ cell development by small molecule screening in ex vivo gonad cultures. BMC Research Notes 6 168. (doi:10.1186/1756-0500-6-168)

Western P 2009 Foetal germ cells: striking the balance between pluripotency and differentiation. International Journal of Developmental Biology 53 393-409. (doi:10.1387/ijdb.082671pw)

Western PS, Miles DC, van den Bergen JA, Burton M \& Sinclair AH 2008 Dynamic regulation of mitotic arrest in fetal male germ cells. Stem Cells 26 339-347. (doi:10.1634/stemcells.2007-0622)

Western PS, van den Bergen JA, Miles DC \& Sinclair AH 2010 Male germ cell differentiation involves complex repression of the regulatory network controlling pluripotency. FASEB Journal 24 3026-3035. (doi:10.1096/ fj.09-151555) 
Western PS, Ralli RA, Wakeling SI, Lo C, van den Bergen JA, Miles DC \& Sinclair AH 2011 Mitotic arrest in teratoma susceptible fetal male germ cells. PLOS ONE 6 e20736. (doi:10.1371/journal.pone.0020736)

Whiting CV, Tarlton JF, Bailey M, Morgan CL \& Bland PW 2003 Abnormal mucosal extracellular matrix deposition is associated with increased TGF-beta receptor-expressing mesenchymal cells in a mouse model of colitis. Journal of Histochemistry \& Cytochemistry 51 1177-1189. (doi:10.1177/002215540305100908)

Wu Q, Kanata K, Saba R, Deng CX, Hamada H \& Saga Y 2013 Nodal/ activin signaling promotes male germ cell fate and suppresses female programming in somatic cells. Development 140 291-300. (doi:10.1242/ dev.087882)
Ying QL, Wray J, Nichols J, Batlle-Morera L, Doble B, Woodgett J, Cohen P \& Smith A 2008 The ground state of embryonic stem cell self-renewal. Nature 453 519-523. (doi:10.1038/nature06968)

Received 31 May 2016

First decision 27 June 2016

Revised manuscript received 20 July 2016

Accepted 5 August 2016 